\title{
THE CONTRIBUTION OF QUALITY EARLY CHILDHOOD EDUCATION AND ITS IMPACTS ON THE BEGINNING OF FUNDAMENTAL EDUCATION $^{1}$
}

\author{
Maria Malta Campos \\ Eliana Bahia Bhering \\ Yara Espósito \\ Nelson Gimenes \\ Beatriz Abuchaim \\ Raquel Valle \\ Sandra Unbehaum \\ Carlos Chagas Foundation
}

\begin{abstract}
This article presents results from a research whose objectives were to evaluate the quality of early childhood education (ECE) in six Brazilian state capitals (quality assessment) and, then, identify differences in school performance of children at the beginning of fundamental education (FE) associate to their attending a good quality ECE school (impact assessment). The impact assessment made use of the results of the quality assessment obtained from the application of grades of quality evaluation to a sample of pre-schools situated in three Brazilian state capitals. These results indicate that the quality level has been compromised in the majority of the institutions evaluated. The sample for the impact assessment was constituted by 762 students from public schools with grades in the Provinha Brasil [National Literacy Exam], from which 605 had attended a pre-school evaluated in the quality assessment, and 157 children who had not attended ECE. The data were treated by multilevel/hierarchical analysis with cross classification, which makes it possible to take into account, simultaneously, the effect of several explicative variables (characteristics of pupils and their families; of the ECE schools and FE schools) upon the results of the response variable (second-year students' grades in the Provinha Brasil). The impact assessment reveals that attending a good quality pre-school has positive effect in the performance of students in the Provinha Brasil. The analyses also indicate that the child's age is an important factor for the results obtained in that exam, as well as mother's level of schooling, family income, and the Ideb result of the ECE attended.
\end{abstract}

Keywords: Early childhood education - Pre-school - Fundamental education - Impact assessment

The new legal regulations instituted since the 1988 Federal Constitution reinforced and legitimized the processes of expansion of the educational service to children between the ages of zero and six years, which had already been happening in previous years with early childhood education (ECE) defined as the first stage of basic education. The responsibility attributed to the municipalities of offering this service with priority has spurred a trend that had also been outlined during the previous period. Although not compulsory, ECE was defined as a right of children and their families, with the State being obligated to offer it according to demand.

\footnotetext{
${ }^{1}$ Supported and sponsored by MEC/BID. We would like to thank the local coordinators of the Project, Ana Tancredi, Sílvia Cruz, Olivetti Aguiar, Regina Marques and Jodete Füllgraf, and the statisticians Dalton de Andrade and Adriano Borgatto for their valuable help to this study.
} 
Since 2000, several changes have been introduced in this legal scenario, forcing the education systems, which were still adjusting to the parameters defined by the Law of Guidelines and Bases $\left(\mathrm{LDB}^{2}\right.$ ) of 1996, to simultaneously implement significant changes in the organization of basic education. Among the measures prescribed by the LDB, which were still only partially implemented, were the incorporation of daycare centers into the education systems, and the education of teachers to higher education level or, at least, to secondary education level.

The present research was developed exactly at that time, when successive legal changes impacted directly on ECE, which had not still consolidated even the organization defined by the LDB. To a transition still in course came to be added: advancing the entry age into first series from seven to six years, the implementation of nine-year fundamental schooling, the creation of Fundeb, and the new definition of mandatory schooling from the age of four.

Despite the progresses made by the country in its ECE, both in respect to the expansion of access, and in the legal guidelines that defined higher standards of service for daycare centers and pre-schools, the available data indicate that many of these guidelines fail to be fully translated into practice, especially in the case of the daycare centers. Studies show also that the differences in quality combined with social and regional differences causing the quality of service, as well as access, to be unevenly distributed among the various segments of the population (Ipea, 2009).

From the point of view of the curriculum and pedagogical guidance, what can be observed is a sharp heterogeneity in the working conditions and work methods adopted with children, with consequences for the quality of the service offered. The situation found in daycare centers is usually worse than that in pre-schools (Unesco/OECD, 2005a; 2005b).

Taking into account the national scenario of ECE described above, which contains so many challenges for public policy, this study was planned in such a way as to include the following objectives:

I. To evaluate the quality of 150 institutions of ECE in six Brazilian state capitals: Belém, Campo Grande, Florianópolis, Fortaleza, Rio de Janeiro, and Teresina (quality assessment).

II. To estimate the impact of attending daycare centers and pre-schools on the performance of students at the beginning of fundamental education (FE) in three of these capitals: Campo Grande, Florianópolis, and Teresina (impact assessment).

III. To characterize the municipal policy for ECE in the six state capitals mentioned above.

The present article will focus particularly on the impact assessment (objective II). However, to better understand the paths followed in the impact assessment, a description of the quality assessment is included, emphasizing the aspects that gave support to the conduction and data analysis of the impact assessment (objective I).

As an introduction to the research, the article presents a survey of the literature on the impact of ECE on FE; next, it describes the main procedures and results of the quality assessment and impact assessment, concluding with some considerations about the results of the research and indications considered relevant to education policies.

\footnotetext{
${ }^{2}$ From the Portuguese Lei de Diretrizes e Bases (Translator's Note).
} 


\section{The impact of attending early childhood education on the learning results at fundamental education}

The opportunity to attend quality ECE is a right of the child and represents a benefit that cannot be measured only in terms of future results, but mainly from the experiences that it affords the child at that stage of his/her life. Nevertheless, from the point of view of public policies, especially in a country like Brazil, in which the education indexes reveal the persistence of important deficits in the basic schooling of the population, the debate about the impact of ECE on further schooling gains meaning, and comprises a range of issues that deserve to be better understood within the Brazilian context.

The specialized literature records a large body of studies that have attempted to assess the impact of ECE on the continuity of schooling. The major part of it tried to measure the results of attending pre-school education programs, and a smaller share also included the daycare centers in their evaluations.

In an article published in 1997, Campos (1997) summarized the results of several of these studies conducted in countries of Latin America, Europe and USA. Most of the studies observed the positive impact of attending pre-school on the results obtained by children in their further education. The duration of this impact varied, according to the study considered, from the first years of primary school up until adult life, according to the well known longitudinal study that followed up the pupils coming out of the Perry Preschool project.

For the daycare centers, the results of two longitudinal researches carried out in the USA have shown the positive impact of attending good quality daycare centers and importance of the relations between institution and families to achieve good results with the children (Campos, 1997, p. 117-121).

One of the studies covered by this survey, the research conducted by the Fundação Carlos Chagas with support of the World Bank, evaluated programs of innovation of basic education adopted by the São Paulo state since the 1980s. The study followed a sample of 3600 children during three years starting at their entering the first series. Multiple regression analysis showed that the "attending pre-school" variable had the largest impact on the grades obtained by the children in language and mathematics exams at three points of their school trajectory (Fundação Carlos Chagas, 1995, apud Campos, 1997, p. 124).

Barnett and Boocock (1998) organized a group of texts that report studies conducted in several countries on the effects of attending early childhood education and care programs upon the cognitive and social development of small children, evaluating the impacts on their school results and social development. The chapters of the book cover in detail studies carried out the United States of America, in other developed countries, and also in developing nations such as India.

Many of these studies attempted to go beyond the measurement of the impacts of attending a variety of programs, exploring also the differences in results that could be attributed to the format, pedagogical model, modalities of family support, factors associated to the quality - teacher education, adult/child ratio, and infrastructure among other aspects.

In most of the researches cited a positive impact was observed upon the cognitive development of the children by the end of the programs, and also afterwards, 
throughout their school careers. Such effects could be attested both in pilot-programs created especially for the development of researches, and in large-scale governmental programs in the USA (Barnett, 1998) and in other countries (Boocock and Larner, 1998). The impact is higher for the groups of children of lower socioeconomic level (Frede, 1998).

The results of the Programme for International Student Assessment - PISA 2003 show the differences in scores achieved by students that attended pre-school as compared to those who did not attend it, for the countries that took part in the assessment. These results were calculated for those who had one year or less in preschool and for those who attended it for more than one year, with and without taking into account the students' socioeconomic background. There were only five among 41 countries for which the differences in favor of those who had had more than one year of pre-school, controlling for background, were not positive. The positive difference obtained for Brazil, following the same criteria - close to 40 out of 120 points - was similar to that obtained for Turkey, Hungary, the Netherlands, and Indonesia (OECD, 2004, p. 244).

In the United Kingdom, a longitudinal study about the supply of pre-school education (EPPE - The Effective Provision of Pre-school Education Project) followed a sample of 3000 children between the ages of 3 and 7 enrolled at 140 centers of ECE of various modalities during two years of the pre-school period and three years of primary school $^{3}$ since 1997. For comparison, the sample also included 200 children who did not attend pre-school when entering primary education at the age of five (Sylva et al., 1999; Sammons et al., 2004). The main objective of this study was to investigate if the action of pre-school was indeed productive for children, in other words, if what they experienced in pre-school made a difference for them and for their education process. Despite being obtained in contexts rather different from those found in Brazil, these results constitute important elements to characterize the quality of ECE, because many of their conclusions can also be confirmed by studies conducted in other countries with realities also different from those of England. Among the results from this first stage of the English study, the following can be pointed out: the experience in pre-school, compared to no experience in pre-school, favors child development, and these effects can still be seen in their intellectual and social development during the first years of primary education; the length of attendance (in months) is important, and starting before the age of three can be related to a better intellectual development by the age of six and seven, and with improvements in autonomy, concentration, and sociability at the beginning of primary school at the age of six; full-time attendance does not lead to better results for the children in comparison with half-period attendance; poorer children, in particular, can benefit significantly from good quality pre-school experience, especially if they attend centers that receive a heterogeneous population from the point of view of their socio origin; the quality of pre-schools is directly related to better results in the intellectual and socio-behavioral development of the children, and these effects persists in the assessments conducted at the age of six and later; the centers with better qualified personnel, particularly with a good proportion of trained teachers, have better quality, and their children exhibit more progress (Sylva et al., 2003; 2004a; 2004b).

\footnotetext{
${ }^{3}$ In England, the years immediately after pre-school, between the ages of 5 and 6, are called "infant school", which is the beginning of primary school, corresponding to "Key Stage 1". In the present text "primary school" is used to refer to the level following pre-school.
} 
One of the questions problematized in this kind of research is the relative impact of the quality of primary school in which children are studying with respect to their previous experience in pre-school education and/or daycare center. As pointed out by Clark (1988), one cannot attribute the decrease in differences of performance in time to the fragility of the impact of pre-school education without taking into account what happens in primary education. This aspect is related to the type of transition that the child faced in the passage to primary schooling.

Today, the concept of readiness, traditionally employed to indicate the preconditions exhibited by the child favorable to his/her adaptation and success in the first series, was revised to include also the readiness of the school, that is, the favorable conditions exhibited by the primary school to receive adequately the children coming out of ECE (Moss, 2008). Another important change regarding the understanding about readiness is due to the influence of Vygotsky's theory, according to which instead of waiting for the child to achieve a given level of development before introducing her to new educational stages, one should offer her opportunities to participate in educative environments where her peers and adults alike foster her development and learning (Kagan, 2007).

These facts reinforce the importance of considering the quality of children's education experiences prior to FE, the type of transition occurring at the moment of entering the first series, and the quality of the education offered by the school of fundamental education at the moment of the evaluation of school results. Today, readiness is therefore understood as a multidimensional concept, including the readiness of families, schools, and communities (Kagan, 2007). As indicated by Moss (2008), it is not enough to require that ECE prepares children for primary school, but we should also demand that schools become receptive for the children entering them.

These are the questions that affect directly the transition from ECE to FE, especially now in Brazil with the age of beginning FE being advanced from seven to six, with the implementation of nine-year FE, and with the adoption of mandatory education from the age of four. 


\section{The quality assessment: methodology and main results}

The quality assessment, a dimension of the research whose objective was to evaluate the environments in which children spend most of their time when at school, was conducted in six Brazilian state capitals, two of them in the Northeast Region, and the others situated in the other four regions of the country. In the cities where the impact assessment was not conducted, namely Rio de Janeiro, Fortaleza, and Belém, 20 municipal, private, and government-funded (conveniadas) institutions were selected for the quality assessment, bringing the total number of institutions assessed to 60; and in the cities were the impact assessment was carried out (Campo Grande, Florianópolis, and Teresina), 30 municipal institutions were selected, taking the total to 90 institutions.

The selection of these institutions was made through sampling of the 2008 School Census database supplied by MEC/Inep (Brasil, 2008), and from data by IBGE on the school neighborhoods, taking into account the following variables: the institution's administrative affiliation; type of establishment; number of students; school hours; localization in boroughs/districts, and average Ideb of the FE schools located in the vicinity of the ECE institutions.

The assessment included 147 institutions (three of them could not take part, and there was no time to replace them), 102 of them (69.4\%) municipal, 23 (15.6\%) private, and $22(15.0 \%)$ government-funded private institutions. As to the type of school, 93 $(63.3 \%)$ received only ECE pupils, while 54 (36.7\%) also enrolled pupils in other segments of schooling.

At each institution one daycare class and/or pre-school class was chosen randomly, in which the selected observation scales were applied after adaptation for this research; additionally, interviews were conducted with the teachers responsible for the class, the pedagogical coordinators - when the institution had one -, and the principals.

\section{Assessment scales for environments of early childhood education}

To assess the quality of ECE institutions, two North American observations scales were selected (Harms, Cryer and Clifford, 1998; 2003) for the daycare and preschool classes, both of them translated by Brazilian researchers.

The Early Childhood Environment Rating Scales (ECERS - Revised) was developed to be used in the observation and assessment of environments and/or programs dedicated to children of ages between two and a half and five, and in the present research this instrument was used with four- to five-year-olds (pre-school). It consists of an observation guideline that comprises seven subscales (space and furniture; personal care routines; language and reasoning; activities; interaction; program structure; and parents and team), with 43 items composed of 470 indicators qualitatively ordered in intervals varying between 1 and 7 points, which constitutes the assessment system.

A rating of 1 corresponds to situations or aspects considered as inadequate; a rating of 3 indicates the set of conditions regarded as minimal; a rating of 5 signals the presence of conditions classified as good, and the rating of 7 corresponds to what is seen as excellent. The scales allow that some items can be rated with NA (not applicable) when a given aspect cannot be assessed because it does not apply to the group observed. The records made by the observer about the presence/absence of the group of indicators in each item are represented by the rating from 1 to 7 . The average rating attributed to 
the set of items that comprise each of the seven subscales indicates the level of quality of the service offered by the institution.

For the present research it was defined that the rating would be translated into a scale from 1 to 10 (Chart 1), to improve the understanding of the results by the school teams and secretariats to which they would be presented in local seminars to be conducted between November 2009 and May 2010.

\section{Chart 1: Classification criteria and rating adopted}

\begin{tabular}{|c|c|}
\hline Classification & Total points \\
\hline Inadequate & $1 \mid-------3$ \\
\hline Basic & $3 \mid-------5$ \\
\hline Adequate & $5 \mid-------7$ \\
\hline Good & $7 \mid-------8.5$ \\
\hline Excellent & $8.5 \mid-------10$ \\
\hline
\end{tabular}

Data collection (for the quality and impact assessments) was made during the second half of 2009 by teams coordinated by teachers from the local federal universities, trained for the task according to the procedures indicated in the scales.

The ECERS-R scale was applied to 138 pre-school classes from the six municipalities researched. The overall average rating was 3.4, corresponding to the basic level of quality. The averages for the subscales Activities and Program Structure were classified as inadequate; the subscales Space and furniture, Parents and team, Language and reasoning, and Personal care routines had an average corresponding to basic; and only the subscale Interaction achieved and average corresponding to adequate (Graph 1). 


\section{Graph 1. Overall average and average for each subscale for the pre-schools - ECERS-R}

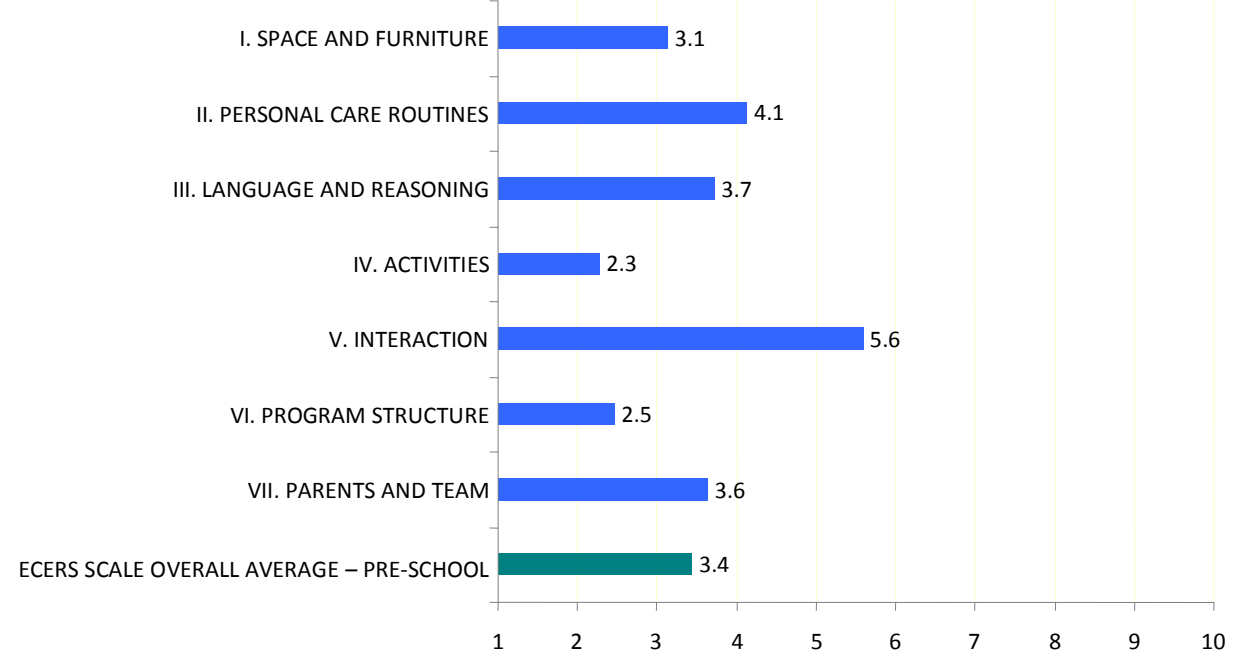

Most of the pre-school classes assessed (42.0\%) achieved ratings between 3 and 5 , corresponding to the basic level of quality. A significant percentage (30.4\%) showed ratings between 1 and 3, which correspond to the inadequate level of quality. A fraction of $23.9 \%$ of the classes was classified as adequate, and only $3.6 \%$ of the classes researched achieved the good level of quality (Graph 2).

\section{Graph 2. Percentage distribution of pre-school classes' ratings in the ECERS-R scale}

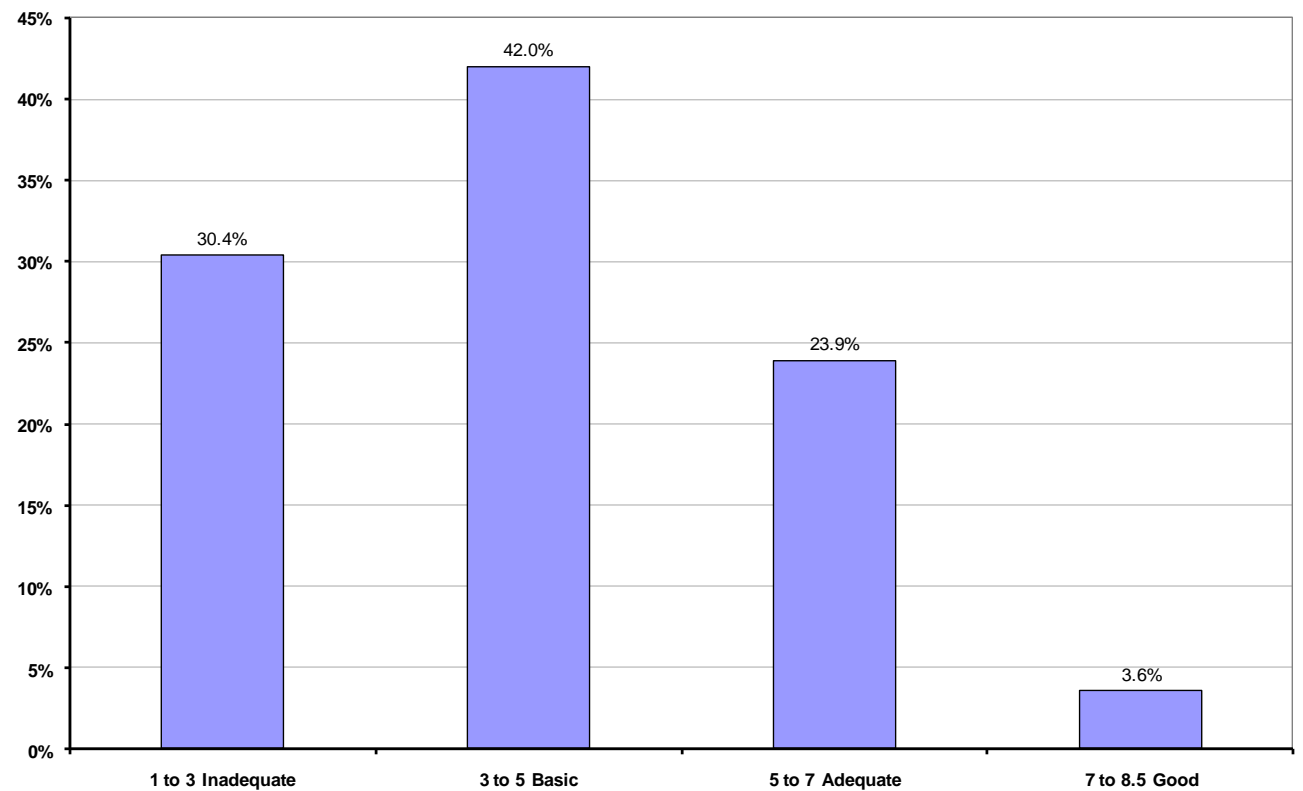


In the capitals were the impact assessment was conducted the average rating was slightly higher than the overall average: 3.7 points, varying among the municipalities (Table 1).

Table 1. Overall average for pre-school classes in the three capitals

\begin{tabular}{|c|c|}
\hline Capitals & $\begin{array}{c}\text { Pre-school classes } \\
\text { average rating }\end{array}$ \\
\hline Campo Grande & 3.6 \\
\hline Florianópolis & 4.7 \\
\hline Teresina & 2.7 \\
\hline $\begin{array}{c}\text { Average of three } \\
\text { capitals }\end{array}$ & 3.7 \\
\hline
\end{tabular}

When comparing the municipalities, we must take into account the regional characteristics, which are rather uneven regarding the funding and the general working conditions of the institutions.

An analysis of the items that compose the subscales indicated that, both in daycare centers and in the pre-schools with the higher ratings, the chances were better of: adequate supervision during the children's sleep; the children having good knowledge of safety rules; good balance between talking and listening; mathematics not being taught in a mechanical and repetitive way; individual expression being more respected; toys, materials, equipment, and clothes being more available for children's pretending games; larger quantity of materials for fine motor skills; children not waiting very long between the daily events, and larger opportunities for children choosing their peers in plays and activities.

\section{The impact assessment: methodology and main results}

\section{The Provinha Brasil}

The Provinha Brasil [National Literacy Exam] is a diagnostic evaluation of the literacy level of children enrolled in the second year of FE at Brazilian state schools, applied at the start and closure of the academic year. The instrument is prepared by Inep, and is composed of 24 multiple choice questions with four alternatives each. The exam is distributed by MEC/FNDE to all municipal and state secretariats, and to that of the Federal District. The main objectives in applying this exam are, according to Inep, to assess the literacy level of pupils/classes at the first years of FE, and to diagnose possible insufficiencies in their reading and writing skills. To guide the grading and interpretation of the results, Inep prepares and distributes to the secretariats an Interpretation Guide. It allows establishing a relation between the number or the average right answers by one or more pupils and the exam's performance levels. It is expected that the results will allow interventions with a view to correct possible insufficiencies exhibited in the areas of writing and reading.

The criteria defined by Inep to identify the performance level of students in 2009 are summarized in Chart 2. 


\section{Chart 2. Correspondence between number of right answers and literacy levels in the Provinha Brasil}

\begin{tabular}{|c|c|l|}
\hline $\begin{array}{c}\text { Number of } \\
\text { right } \\
\text { answers }\end{array}$ & $\begin{array}{c}\text { Literacy } \\
\text { Level }\end{array}$ & \multicolumn{1}{|c|}{ Examples of skills } \\
\hline Up to 10 & 1 & $\begin{array}{l}\text { Recognizes some letters, syllables } \\
\text { and letter sounds, and reads words } \\
\text { formed by simple syllables. }\end{array}$ \\
\hline 11 to 15 & 2 & $\begin{array}{l}\text { Recognizes some letters written in } \\
\text { different ways; some simple words; } \\
\text { and different styles of simple texts. }\end{array}$ \\
\hline 16 to 18 & 3 & $\begin{array}{l}\text { Reads more complex words, short } \\
\text { sentences, and identifies explicit } \\
\text { information in the text. }\end{array}$ \\
\hline 23 to 24 & 4 & $\begin{array}{l}\text { Localizes explicit information in the } \\
\text { text; is capable of better } \\
\text { understanding the text, and to } \\
\text { identify the text's style. }\end{array}$ \\
\hline & 5 & $\begin{array}{l}\text { Has command of the writing system } \\
\text { and understanding of the alphabetic } \\
\text { system, and understands informative } \\
\text { texts with complex vocabulary. }\end{array}$ \\
\hline
\end{tabular}

Source: Inep, 2009.

\section{Family questionnaires}

A questionnaire was prepared to be answered by the families of FE second-year pupils with the objective of gathering information such as the socioeconomic data, and the trajectory and duration of pre-school experience of their children. With the results of these questionnaires the intention was of presenting a detailed description of the school trajectory of a sample of pupils and their families between pre-school and the second year of FE. The intention was then to compare and contrast the performance of a group of pupils with wide-varying socioeconomic and cultural backgrounds, who had had different pre-school experiences, with the performance of a control group composed by pupils who started FE without having gone through an ECE institution.

This questionnaire was answered by two groups of parents:

a) parents of pupils enrolled in the second year of FE, who had attended an ECE class in one of the institutions assessed by the research or in a non assessed ECE institution;

b) families of pupils who were attending the second year, but who had initiated their schooling without having attended a daycare center or pre-school.

The sample of pupils for the impact assessment 
The precondition to take part in this study was the existence and availability of individual grades in the Provinha Brasil for the first semester of 2009 from the pupils at the second year of FE. Thus, after consulting with the municipal governments, three capitals - Campo Grande, Florianópolis, and Teresina - were selected based on this criterion. The pupils' individual grades were given to the research team by the secretariats of education of these municipalities.

The procedures adopted to select the families that comprised the sample for this part of the study were:

- organization, based on the 2008 School Census, of a list containing the names of the children who had attended in 2007 one of the ECE institutions belonging to the study sample, and identification of the FE schools at which these children were enrolled in 2009;

- collection, with the secretariat of education of the chosen municipalities, of the results from Provinha Brasil relative to the pupils from the FE schools of interest to the present study ("destination" schools for the children);

- identification, for each FE school, of the classes with the highest number of pupils who had attended ECE at one of the units from the sample ("origin" schools), and which had grades in the Provinha Brasil;

- identification, for each FE school, of the number of classes at which questionnaires should be distributed, having defined that in each school at least two classes should be selected, and that every pupil from these classes should receive a questionnaire to be answered by their parents. With this strategy the intention was of obtaining greater diversity of the families included.

With the results from these procedures, questionnaires were sent to 134 classes from $58 \mathrm{FE}$ schools, with a total of 4020 instruments. After a careful process of consistency-checking, the final basis was constituted by 1156 questionnaires, with a significant variation across municipalities (Table 2). The questionnaires were answered by the parents of pupils attending 58 public FE schools, the majority of them $(95 \%)$ belonging to the municipal school systems.

Table 2. Number of valid questionnaires per municipality

\begin{tabular}{|c|c|c|}
\hline Municipality & $\mathbf{N}$ & \% \\
\hline Campo Grande & 616 & 53.3 \\
\hline Teresina & 356 & 30.8 \\
\hline Florianópolis & 184 & 15.9 \\
\hline Total & 1156 & 100.0 \\
\hline
\end{tabular}

Considering that one of the questions of interest to the study was to find out whether not just attending ECE, but also its quality, were associated to the performance of pupils in FE, some adjustments had to be made in the sample. Since the measure of the quality of ECE to be used was that of the pre-school scale (ECERS-R), the children who attended only daycare centers (115 cases) were not included in the study. Additionally, pupils who attended pre-schools not assessed by the research ( 279 cases) were also excluded. Therefore, the final sample for the impact assessment included 762 
second-year pupils from 55 FE schools. From among the 762 pupils, 605 had attended a pre-school evaluated in the quality assessment, and 157 comprised the control group, that is to say, the group of children who had never attended ECE (neither daycare centers nor pre-schools). The impact study included 68 ECE schools, since the pupils coming from the other 20 schools assessed were scattered through a large number of FE schools, making it impossible to include all of them in the study.

\section{Data analysis and results}

\section{Results from the Provinha Brasil}

Table 3 shows that the group of children who attended pre-school achieved higher average grading in the exam when compared to the control group.

The results of pupils who came out of pre-schools evaluated as of good, intermediate, and low quality can be seen in Table 4, revealing that pupils who attended good quality pre-schools exhibit better results in the Provinha Brasil when compared to the other groups. Their results are better even when compared to the average of the whole group of pupils considered here.

Confirming results from other studies, it was observed that girls achieved better results, with an average of 18.0, whereas boys obtained a lower average of 16.5.

Table 3. Averages in the Provinha Brasil according to groups of pupils

\begin{tabular}{|l|c|c|c|c|}
\hline $\begin{array}{l}\text { Attendance to } \\
\text { ECE }\end{array}$ & $\mathbf{N}$ & \% & Average & SD \\
\hline Control group & 157 & 20.6 & 16.1 & 5.4 \\
\hline ECE group & 605 & 79.4 & 17.5 & 5.1 \\
\hline Total & 762 & 100.0 & 17.2 & 5.1 \\
\hline
\end{tabular}


Table 4. Averages in the Provinha Brasil according to quality of ECE

\begin{tabular}{|l|c|c|c|c|}
\hline $\begin{array}{l}\text { Quality of pre- } \\
\text { school }\end{array}$ & $\mathbf{N}$ & $\%$ & Average & SD \\
\hline Inadequate & 115 & 15.1 & 17.5 & 5.7 \\
\hline Intermediate & 260 & 34.1 & 17.0 & 5.0 \\
\hline Adequate & 230 & 30.2 & 18.1 & 4.7 \\
\hline Control group & 157 & 20.6 & 16.1 & 5.4 \\
\hline Total & 762 & 100.0 & 17.2 & 5.1 \\
\hline
\end{tabular}

Graph 3 presents the results of Provinha Brasil with respect to age group, showing that the highest average are found in the age group between 7.5 and 8 years, the expected age for second-year FE pupils, who should have come to the first series at the age of six. Both younger and older children scored lower averages, suggesting that the age at which children enter FE is a factor associated to the results measured by Provinha Brasil at the public schools.

\section{Graph 3. Averages in the Provinha Brasil according to age group}

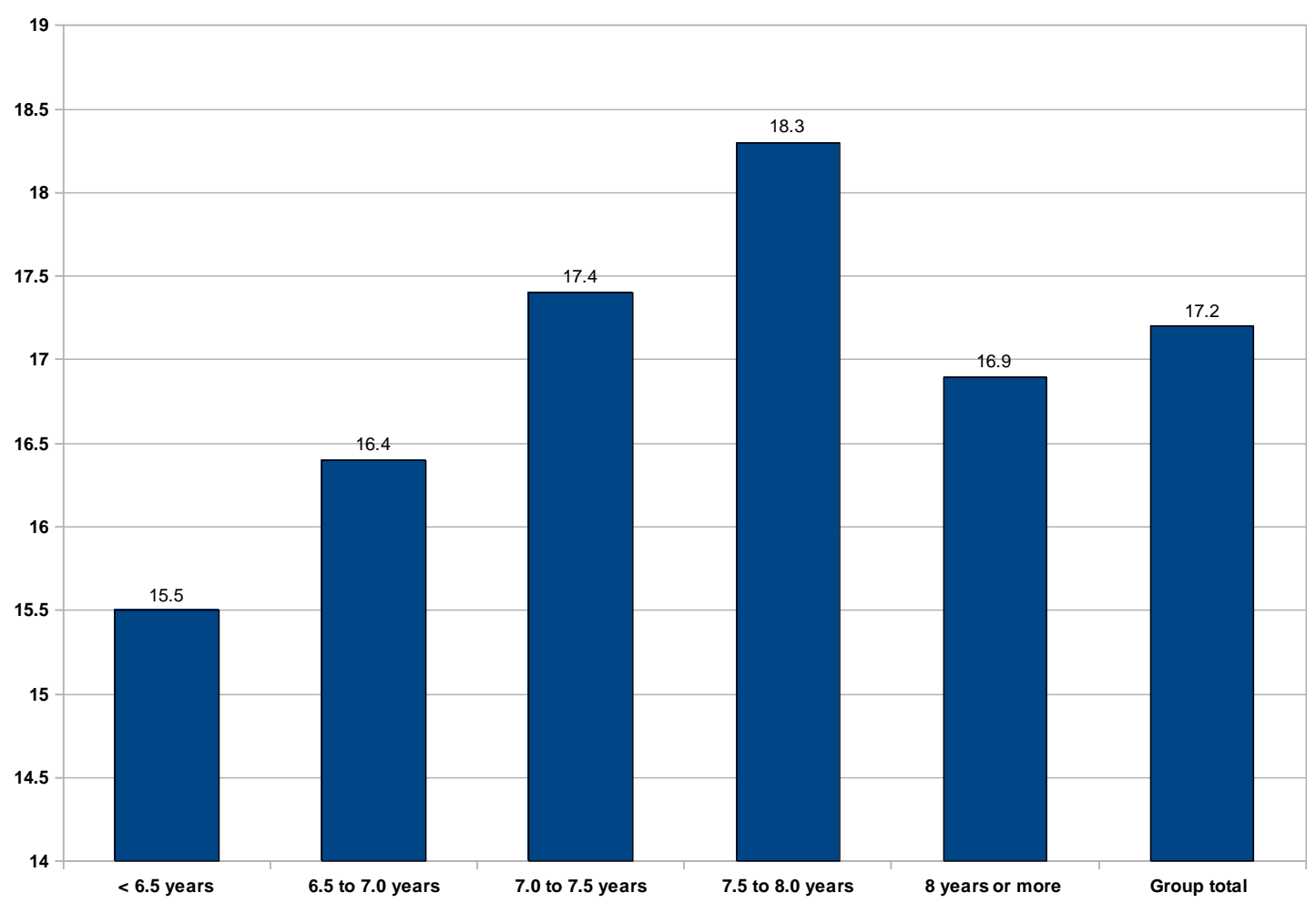




\section{Family questionnaire}

The analysis of the information supplied by the parents of pupils at the second year of FE involved tabulating the answers given by the members of the two groups of interest - the group who had attended an ECE class, and the control group - and the study of the characteristics of the pupils and of their family context, associated to obtaining different results in the Provinha Brasil.

Table 5 shows the distribution of the groups of pupils according to family income. In both groups, around two thirds of the pupils belong to families with a monthly income below two minimum wages (74.7\% of the ECE group; $64.3 \%$ of the control group).

Table 5. Family income according to reference groups

\begin{tabular}{lcccccc}
\multicolumn{1}{c}{ Family income } & \multicolumn{2}{c}{ ECE group } & \multicolumn{2}{c}{ Control } & \multicolumn{2}{c}{ Total } \\
& \multicolumn{2}{c}{ group } & & \\
& $\mathrm{N}$ & $\%$ & $\mathrm{~N}$ & $\%$ & $\mathrm{~N}$ & $\%$ \\
Up to 1 MW - R\$ 465.00 & 248 & 41.0 & 52 & 33.1 & 300 & 39.4 \\
1 to 2 MWs & 204 & 33.7 & 49 & 31.2 & 253 & 33.2 \\
2 to 4 MWs & 99 & 16.4 & 33 & 21.0 & 132 & 17.3 \\
> 4 MWs & 32 & 5.2 & 12 & 7.6 & 44 & 5.8 \\
No information & 22 & 3.6 & 11 & 7.0 & 33 & 4.3 \\
Total & 605 & 100.0 & 157 & 100.0 & 762 & 100.0
\end{tabular}

Table 6 shows the level of schooling of fathers and mothers. More than $40 \%$ of the fathers in both groups and of mothers in the control group did not complete FE or did not attend school. For the mothers in the ECE group this percentage was $35 \%$. The number of fathers and mothers who completed higher education is insignificant in this sample. Also, a larger percentage of mothers completed secondary schooling when compared to fathers.

Table 6. Father and mother schooling according to reference groups

\section{Schooling}

Did not attend school/ FE

incomplete

$\mathrm{FE} / \mathrm{SE}$ incomplete

SE/HE incomplete

$\mathrm{HE}$

Do not know/No information

Totals
ECE group

$\begin{array}{cc}\text { Father } & \text { Mother } \\ \% & \%\end{array}$

46.3

22.5

21.6

0.8

8.7

100.0

$\mathrm{N}=605$
35.1

32.7

28.5

1.7

2.1

100.0

$\mathrm{N}=605$
Control group

$\begin{array}{cc}\text { Father } & \text { Mother } \\ \% & \%\end{array}$

46.5

18.5

41.4

18.5

22.3

25.5

2.5

14.0

3.2

7.7

100.0

Variables and indicators already selected for the quality assessment, associated to those chosen from the analysis of the information obtained through the family 
questionnaire, were used when applying the methodology of analysis whose results will be presented ahead in the statistical analysis. Table 7 collects the set of variables considered in the analysis.

\section{Statistical analysis ${ }^{4}$}

The objective of the statistical analysis was studying the contribution of the attendance to ECE to the learning results in FE, as measured by the Provinha Brasil, taking into account the characteristics of the ECE and FE institutions and some pupilrelated variables obtained from family questionnaires.

The analysis employed was a multilevel/hierarchical analysis with crossclassification (Raudenbush, Bryck, 2002). Hierarchical analysis is a regression analysis that considers a group structure or hierarchy of the data. The cross hierarchical model takes into account that students may be grouped within level 2 (school level) in two different ways: according to the ECE institution where they attended pre-school or according to the FE school they were attending now. Because it is a hierarchical model, the response variable must be a measure from level 1 - student level -, which in this case was the result in the Provinha Brasil. The explicative variables were of three types: characteristics of the pupil, of the ECE institution, or of the FE school.

Five models were used to study the impact of pre-school in the learning results of FE students. Summarizing the analyses of the first four models, the conclusion is that there is an effect of FE, that is to say, differences between the FE schools influence the students' performance in the Provinha Brasil; there exists an effect of ECE, in other words, attendance to ECE influences the results obtained by the pupils; and there is an effect of ECE and FE, when considered simultaneously, in the pupils' performance. When considered simultaneously, there is an effect of FE and of the quality of preschool in the learning results as measured by the grades in the Provinha Brasil. The best performance is achieved, in average, by pupils who attended good quality pre-schools.

The last model adjusted was a two-level hierarchical cross model with the presence of explicative variables in both levels. Through statistical analysis it was possible to conclude that the best performance in the Provinha Brasil was reached by pupils with the following profile:

- $\quad$ age corresponding to the expected age for the $2^{\text {nd }}$ grade;

- has never failed school;

- attended good quality pre-school;

- live in a family with income above two minimum wages;

- mother's schooling corresponds at least to complete secondary education;

- attend FE schools located in neighborhoods with a proportion of heads of households with 15 years or more of schooling of at least 5\%;

- the Ideb of the FE school attended is high.

Table 7. List of explicative variables considered in the analysis

Variable Description

Level 1 - student

\footnotetext{
${ }^{4}$ For further details about the statistical treatment, see Fundação Carlos Chagas (2010).
} 


\begin{tabular}{|c|c|}
\hline Age & Student's age, in years \\
\hline Father's schooling & $\begin{array}{l}\text { Father's schooling: up to incomplete secondary schooling, } \\
\text { complete secondary schooling, or more }\end{array}$ \\
\hline Mother's schooling & $\begin{array}{l}\text { Mother's schooling: up to incomplete secondary } \\
\text { schooling, complete secondary schooling, or more }\end{array}$ \\
\hline Family income & $\begin{array}{l}\text { Family income: up to } 2 \text { minimum wages or more than } 2 \\
\text { minimum wages }\end{array}$ \\
\hline Number of people in household & $\begin{array}{l}\text { Including the child, how many people live in the } \\
\text { household: up to } 4 \text { people or more than } 4 \text { people }\end{array}$ \\
\hline Repetition & $\begin{array}{l}\text { Whether or not the child has repeated the } 1^{\text {st }} \text { or } 2^{\text {nd }} \text { grade: } \\
\text { yes or no }\end{array}$ \\
\hline Talks about the school & $\begin{array}{l}\text { Whether or not the parents talk to the child about the } \\
\text { school: yes, no, no information }\end{array}$ \\
\hline Time in ECE & $\begin{array}{l}\text { Period of attendance to ECE: never attended (control), } \\
\text { attended only pre-school, or attended ECE and pre-school }\end{array}$ \\
\hline \multicolumn{2}{|l|}{ Level 2 - ECE school } \\
\hline Quality of pre-school & $\begin{array}{l}\text { Measure of quality of the pre-school obtained from the } \\
\text { application of the ECERS-R scale }\end{array}$ \\
\hline Attendance to ECE & $\begin{array}{l}\text { Modality of attendance to ECE institution: never attended } \\
\text { (control), attended only ECE, or attended ECE and others }\end{array}$ \\
\hline Administrative affiliation & $\begin{array}{l}\text { Administrative affiliation of the ECE institution: never } \\
\text { attended (control), municipal, or government-funded }\end{array}$ \\
\hline \multicolumn{2}{|l|}{ Level 2 - FE school } \\
\hline Attendance to FE & $\begin{array}{l}\text { Modality of attendance to FE school: FE without ECE, or } \\
\text { FE with ECE }\end{array}$ \\
\hline 15 plus years of schooling & $\begin{array}{l}\text { Indicator of percentage of heads of household in the } \\
\text { neighborhood with } 15 \text { or more years of schooling: low } \\
\text { (less than 5\%) or high (at least 5\%) }\end{array}$ \\
\hline Success rate & $\begin{array}{l}\text { Indicator of the rate of success in the } 2^{\text {nd }} \text { grade: low/no } \\
\text { information, or high (equal to or above } 91 \% \text { ) }\end{array}$ \\
\hline Ideb 2007 & $\begin{array}{l}\text { Measure of the quality of FE school - Ideb 2007: low/no } \\
\text { information, or high (equal to or above 5.0) }\end{array}$ \\
\hline
\end{tabular}

Source: IBGE, 2000; Inep, 2007. 
Table 8.Residual variance of the final hierarchical cross model

\begin{tabular}{|c|c|c|}
\hline Variable excluded from the model & Variance & $\begin{array}{c}\text { Reduction in } \\
\text { variability } \\
\end{array}$ \\
\hline Complete model & 23.560 & \\
\hline \multicolumn{3}{|l|}{ Level 1 - pupil } \\
\hline Family income & 24.053 & $2.0 \%$ \\
\hline Mother's schooling & 23.855 & $1.2 \%$ \\
\hline Age & 24.078 & $2.2 \%$ \\
\hline Repetition & 23.914 & $1.5 \%$ \\
\hline \multicolumn{3}{|l|}{ LEVEL 2a - ECE } \\
\hline Pre-school quality & 23.866 & $1.3 \%$ \\
\hline \multicolumn{3}{|l|}{ LEVEL $2 \mathbf{b}$ - FE } \\
\hline 15 years or more of schooling & 24.029 & $2.0 \%$ \\
\hline \multirow[t]{2}{*}{ Ideb 2007} & 23.774 & $0.9 \%$ \\
\hline & & $11.1 \%$ \\
\hline
\end{tabular}

It can be seen in Table 8 that the amount of reduction in variability due to each variable is similar. Still, those that showed greater influence on the pupil's result in the Provinha Brasil were: pupil's age, family income, and level of schooling of the population of the school's neighborhood. All variables together explain $11.1 \%$ of the observed differences in performance of the pupils in the Provinha Brasil.

The results from the group of analyses show also that, other conditions being the same, students who attended a good quality ECE, when compared to their colleagues who did not attend pre-school, obtained grades on average 2.9 points higher, corresponding to an increase of $12 \%$ in the grade scale of the Provinha Brasil.

\section{Final considerations}

The legal changes that led to the implementation of the nine-year fundamental education in Brazil adopted as their strategy the incorporation of the last year of preschool to FE, expanding the first stage of this period of schooling from 4 to 5 years, and bringing forward the child's entry into FE to the age of six. Such design implies reducing pre-school from three to two years, corresponding to the age group between four and five, instead of between four and six.

It can be argued that what was attempted with these new legal measures was to speed up the universalization of the education service to six-year-olds, an intention 
reinforced by the adoption of mandatory schooling for the age between four and seventeen.

However, this new organization of schooling has been adopted without guaranteeing first that FE schools had appropriate infrastructure, teacher education, reduction of number of pupils per class, adaptation of curricula, and didactic material, amongst other conditions, in order to allow a smoother transition toward the new format. On the contrary, the lack of definition of the exact age limits for pupil transfer from one stage to another, the pressure exerted by the Justice on many of the public school systems, and the deficiencies exhibited by the FE schools in receiving younger pupils are some of the new problems that have been added to the older ones, and which have still not been solved by the basic education in the country.

These are hindrances and difficulties identified in the public school systems of the capitals studied during this investigation. It was observed that such problems occur in parallel to the efforts made by the municipal governments to fulfill the demand for school places in ECE, to integrate the service previously under the responsibility of the state school systems, and to adapt the government-funded institutions to the standards adopted in the education sector, an effort that in some of these towns has caused the municipalization of government-funded institutions and changes in the system of personnel hiring (Fundação Carlos Chagas, 2010).

All these changes and their circumstances have important effects both on the quality of the ECE institutions and on the type of transition experienced by the pupils when they move from ECE to FE. They also have repercussions to the way in which families are organized in respect to their children's school in aspects such as school hours, characteristics of the institutions, school requirements, and others.

As a contribution to a better understanding of this process, this article has presented results of a research whose objectives were to evaluate the quality of ECE institutions in six Brazilian state capitals, and to examine what is the impact of the quality of pre-school upon the learning results exhibited by pupils from the second year of FE. The specialized literature recognizes that the child benefits, both in the present and in his/her future schooling, from the opportunity to enter ECE, and these effects are so much more positive as the better is the quality of that education, and are the more significant to the poorer children.

The research conducted, despite having its fieldwork occurring in 2009, when the municipalities studied still experienced a rather confusing situation with respect to the transition from pre-school to FE, confirmed these conclusions: controlling for the effect of other factors, the access to a good quality pre-school does make a difference to the learning results at the second year, as measured by the Provinha Brasil. It should be noted that the sample was composed of children from public schools, most of them with family income below two minimum wages.

As expected, the quality of the FE school as measured by its Ideb and the situations of income, schooling, and family attitude toward the education of their children also contribute to positive results.

Another important conclusion for public policies has emerged from this investigation: the age at which the child enters the first year and reaches the second is associated to his/her grades in the Provinha Brasil, suggesting that pupils who are too young, and pupils with some school delay, do not perform as well as the others in the public school. 
There is also another interesting aspect to be mentioned about the results produced by this research. There is, in fact, an ongoing debate about the kind of curriculum that should be adopted by ECE. The proposals differ as to the space that should be dedicated to play, to creative activities, and to the free child expression, relative to guided activities of reading and writing, and to the teaching of disciplinary contents. The form of space and time organization in pre-schools also varies widely, according to the different curriculum guidelines: at one extreme we find the traditional school model, in which the teacher addresses the whole group, so as to make all pupils perform the same tasks at the same time and, at the other extreme, there are proposals which focus almost exclusively on guaranteeing room for play and self-initiated free activities.

The instrument employed in the research to measure the quality of pre-school classes is based on a curriculum proposal that values child initiative, offering a multiplicity of situations for experimenting, learning, and expression in ECE daily life, without neglecting the importance of the various types of knowledge in this stage of the development of the child. A school that fails to offer conditions for make-believe games, for art and movement activities, for the development of curiosity and of the child's ability to explore - which includes working with several areas of knowledge -, and does not associate caring to education, is not well evaluated in this observation scale. Now, what the impact assessment revealed was that the type of curriculum guidance associated to better performance at an exam focused on the learning of reading and writing at the start of FE is precisely the model valued in the assessment instrument adopted.

Some studies have attempted to investigate the mediations existing in the relations between curriculum models and type of work developed by the teachers with their ECE pupils, and the cognitive and socio-emotional development of the children in their subsequent school life. Case studies conducted within the EPPE project in the United Kingdom tried to investigate more closely the interactions between adults and children in the ECE institutions whose students performed better at primary education. These are exciting results from the pedagogical point of view, which suggest that the situations where there is balance between child-initiated activities and adult intervention, in the sense of stimulating child curiosity about several types of knowledge ${ }^{5}$, lead to better learning results (Siraj-Blatchford et. al., 2003, p. 123-142).

Studies with a stronger focus on the dynamics taking place at the "heart of the classrooms" (Carvalho,1999) would be timely in Brazil in order to enhance the objectivity of the debate about the pedagogical projects in existence in society today such as, for example, studies evaluating the differential impact of distinct pedagogical proposals.

A better knowledge of this delicate transition from ECE to FE school has also become urgent. The efforts resulting from the social struggles and successive interventions in ECE during the last years, which allowed significant expansion of access and initiatives aiming at improving the quality of service, cannot be put to waste by clumsy transition processes without proper consideration for children, families, and teachers who suffer their consequences.

In addition to that, the results of this study reinforce the urgent need to adopt measures of educational policy that bring gains of quality in ECE, both in daycare

\footnotetext{
${ }^{5}$ The study refers to adult-child interactions that lead to shared processes that keep thinking active (sustained shared thinking) both in children-initiated situations and in those proposed by teachers.
} 
centers and pre-schools. The data obtained in the quality assessment point to specific aspects of the working of daycare centers and pre-schools which necessitate better infrastructure preconditions, better guidance, continued personnel education - which includes managers and technical teams at secretariats - and more efficient systems of supervision. As showed here, these actions can have positive effects not only on the quality of ECE, but also on the better learning opportunities given to children in the continuation of their schooling.

\section{References}

BARNETT, W. S.; BOOCOCK, S. S. (orgs.). Early care and education for children in poverty. Program, and long-term results. New York: State University of New York Press, 1998.

BARNETT, W. S. Long-term effects on cognitive develoomnt and scholl success. In: ; BOOCOK, S. S. (orgs.). Early care and education for children in poverty. Program and long-term results. New York: State University of New York Press, 1998, p.11-44.

BOOCOCK, S. S.; LARNER, M. Long term outcomes in other nations. In: BARNETT, W. S. \& BOOCOCK, S. S. (orgs.). Early care and education for children in poverty. Program and long-term results. New York: State University of New York Press, 1998, p. 45-76.

BRASIL. Ministério da Educação - MEC/Instituto Nacional de Estudos e Pesquisas Educacionais "Anísio Teixeira" - Inep. Microdados do censo escolar 2008. Brasília, 2008.

CAMPOS, M. M. Educação infantil: o debate e a pesquisa. Cadernos de Pesquisa, ${ }^{\circ}$. 101, p. 113-127, Jul. 1997.

CLARK, M. M. Children under five: Education research and evidence. Londres: Gordon and Breach Science Publishers, 1988.

CARVALHO, M. P. No coração da sala de aula: gênero e trabalho docente nas séries iniciais. São Paulo: Xamã/Fapesp, 1999.

FREDE, E. C. Preschool program quality in programs for children in poverty. In: BARNETT, W. S.; BOOCOCK, S. S. (orgs.). Early care and education for children in poverty. Promises, programs and long-term results. New York: State University of New York Press, 1998, p. 77-98.

FUNDAÇÃO CARLOS CHAGAS. Avaliação do processo de inovações no Ciclo Básico e seu impacto sobre a situação de ensino-aprendizagem na Região Metropolitana de São Paulo. São Paulo: Fundação Carlos Chagas, v. 1, 1995. $\left(12^{\circ}\right.$ Relatório Técnico)

Educação infantil no Brasil: avaliação qualitativa e quantitativa (Relatório Final). São Paulo: Fundação Carlos Chagas, 2010.

HARMS, T.; CLIFFORD, R. M.; CRYER, D. Early childhood environment rating scale. Revised Edition. New York: Teachers College Press, 1998.

Infant-toddler environment rating scale. Revised Edition. New York: Teachers College Press, 2003. 
IPEA. Instituto de Pesquisa Econômica Aplicada. PNAD 2008: primeiras análises educação, gênero, migração. Brasília: IPEA, Oct. 2009. (Comunicado da Presidência $n^{\circ} .32$ )

KAGAN, S. Readiness - multiple meanings and perspectives. In: MOSS, P.; WOODHEAD, M. (eds.). Early childhood and primary education. Transitions in the lives of young children. Milton Keynes: The Open University, 2007, p. 14. (Early Childhood in Focus 2)

MOSS, P. What future for the relationship between early childhood education and care and compulsory schooling? Research in Comparative and International Education, Didcot, v. 3, no. 3, 2008, p. 224-234.

OECD. Organization for Economic Co-operation and Development. Learning for tomorrow world. First results from PISA 2003. OECD, 2004. Available at: www.pisa.oecd.org/document/55/. Accessed on 22 Nov. 2010.

RAUDENBUSH, S. W.; BRYK, A. S. Hierarchical linear models: applications and data analysis methods. Newburg Park: Sage, 2002.

SAMMONS, P. The continuing effects of pre-school education at age 7 years. London: Institute of Education, University of London, 2004. (Technical Paper 11)

SIRAJ-BLATCHFORD, I. et al. Intensive case studies of practice across the foundation stage. London: Institute of Education, University of London, 2003. (Technical Paper 10)

SYLVA, K. et al. An introduction to the EPPE project. London: Institute of Education, University of London, 1999. (Technical Paper 1)

The Effective Provision of Pre-school Education (EPPE) project: findings from the pre-school period. London: Institute of Education, University of London, Oct. 2003. (Research Brief $\mathrm{n}^{\circ}$. RBX15-03) Available at: www.ioe.ac.uk/school/ecpe/eppe/. Accessed on 22 Nov. 2010.

The Effective Provision of Pre-school Education (EPPE) project: findings from pre-school to end of key stage 1. London: Institute of Education, University of London, Nov. 2004a. (Sure Start, Evidence \& Research). Available at: www.ioe.ac.uk/schools/ecpe/eppe/. Accessed on 22 Nov. 2010.

The Effective Provision of Pre-school Education (EPPE) project: findings from the early primary years. London: Institute of Education. University of London, November, 2004b. (Sure Start, Evidence \& Research). Available at: www.ioe.ac.uk/schools/ecpe/eppe/. Accessed on 22 Nov. 2010.

UNESCO. United Nations Educational, Scientific and Cultural Organization \& OECD Organization for Economic Co-operation and Development. Early childhood care and education in Brazil. Policy Review Report. Paris: Unesco, 2005a.

Preliminary observations of the review mission to Brazil. Unesco/OECD Early Childhood Policy Review Project. s. 1.: Unesco/OECD, May 2005 b. 
Maria Malta Campos (mcampos@fcc.org.br), Eliana Bahia Bhering (ebhering@fcc.org.br), Yara Esposito (yesposito@fcc. org.br), Nelson Gimenes (ngimenes@fcc.org.br), Beatriz Abuchaim (babuchaim@fcc.org.br), Raquel Valle (rvalle@fcc.org. br) and Sandra Unbehaum (sandrau@fcc.org.br) were part of the team that conducted the study "Early Childhood Education in Brazil: qualitative and quantitative assessments", and are members of the Department of Educational Research of the Carlos Chagas Foundation, São Paulo. 